\title{
THE PUBLIC SECTOR PURCHASE PROGRAMME RULING OF THE GERMAN FEDERAL CONSTITUTIONAL COURT AND THE EUROPEAN UNION LEGAL ORDER**
}

The ruling of the Federal Constitutional Court (FCC) of Germany regarding the EU's Public Sector Purchase Programme represents a striking new element in the judicial dialogue between the FCC and the Court of Justice of the European Union (CJEU) which not only has consequences for the aforementioned EU programme, but may have serious repercussions in a broader sense as regards the relationship between EU law and national constitutional law - as well as national constitutional courts and the CJEU. This paper looks at the central arguments of the GFCC ruling in this context and attempts to draw some conclusions regarding the future of the aforesaid relationship.

Keywords: Public Sector Purchase Programme, Bundesverfassungsgericht, constitutional identity, ultra vires acts

\section{INTRODUCTORY REMARKS}

The relationship between national law and EU law is something of an "evergreen" of EU law research. As is known, the relationship between these two legal orders is generally seen as different from the relationship between national law and international law and is famously governed not by written treaty law, but the case law of the CJEU - the Van Gend en Loos ${ }^{1}$ and Costa ${ }^{2}$ judgments are regarded as two fundamental pillars of the EU legal order, without which the autonomy of the EU legal order cannot be effectively maintained. In Costa, the principle of the primacy of EU law was established, and even

\footnotetext{
* PhD, Associate professor, University of Pécs Faculty of Law, Department of International and European Law. Email: mohay.agoston@ajk.pte.hu. ORCID ID: 0000-0002-1166-2400.

** This research was supported by the Hungarian Scientific Research Fund (OTKA) Research Project K-128796

${ }^{1}$ Case 26/62 Van Gend en Loos v. Nederlandse administratie der belastingen [EU:C:1963:1].

${ }^{2}$ Case 6/64 Costa v. E.N.E.L. [EU:C:1964:66].
} 
without codification into written EU primary law (i.e. the Treaties) ${ }^{3}$ it serves as an accepted concept. The primacy of EU law over national law is generally not questioned by the EU Member States: as "Masters of the Treaties", the Member States would have the possibility to expressly rule out this principle in the text of the Treaties, but no such attempts have been made since the Costa judgment. In the view of the CJEU, EU law has absolute primacy which includes primacy over national constitutions. ${ }^{4}$

However, the relationship between EU law and national constitutions is a more complex issue if viewed from the perspective of national constitutional courts. This more nuanced view is arguably supported by the so-called "identity clause" which in its current form was introduced by the Treaty of Lisbon. According to Article 4 (2) TEU, the Union shall respect Member States' national identities, "inherent in their fundamental structures, political and constitutional, inclusive of regional and local self-government."Judicial dialogue regarding the question of primacy vis-à-vis constitutions nevertheless started much earlier than the Lisbon Treaty: it was the FCC of Germany which first purported to draw a line, in the context of fundamental rights, in its "Solange I" judgment and claim a right to review EU law as regards fundamental rights enshrined in the Grundgesetz (the German Federal Constitution) as long as EU law did not accord the same level of protection to fundamental rights as the Grundgesetz itself. ${ }^{5}$ Even without analysing in detail the later case law of the FCC (which modified and refined the court's position) or other constitutional courts, Solange I can be seen as the starting point of a judicial dialogue concerning constitutionally relevant issues in the EU context focusing among other things of fundamental rights, ultra vires acts of the EU and the question of what the national constitutional identity of an EU member state actually encompasses - and in what way the identity clause would protect this specific identity "against" (?) EU law. ${ }^{6}$ It is against this backdrop that the FCC has delivered a controversial ruling at an already very difficult time for Europe.

\footnotetext{
${ }^{3}$ The EU member states however did put the principle of primacy into a legally non-binding declaration attached to the Lisbon Treaty in 2007. See Declaration concerning primacy, annexed to the Final Act of the Intergovernmental Conference, Official Journal of the European Union C 115 (2008).

${ }^{4}$ See most notably Case 11/70 Internationale Handelsgesellschaft mbH v Einfuhr- und Vorratsstelle für Getreide und Futtermittel [EU:C:1970:114] (para 3) and Case 106/77 Amministrazione delle Finanze dello Stato v Simmenthal SpA [EU:C:1978:49] (paras. 21-26.) For analysis of this position see Von Bogdandy, A.\& Schill, S. 2011. Overcoming Absolute Primacy: Respect for National Identity under the Lisbon Treaty, Common Market Law Review,48(5), pp. 1417-1454.

${ }^{5}$ BVerfGE 37, 271 (Solange I Urteil), para 56.

${ }^{6}$ For good insights into various aspects of this complex issue, see for example Saiz Arnaiz, A. \&Alcoberro Llivina, C. 2011.National Constitutional Identity and European Integration. Cambridge: Intersentia, 2013, and Konstadinides, T. 2011. Constitutional Identity as a Shield and as a Sword: The European Legal Order within the Framework of National Constitutional Settlement. Cambridge Yearbook of European Legal Studies, Vol 13, pp. 195-218.
} 


\section{THE PSPP RULING OF THE FEDERAL CONSTITUTIONAL COURT OF GERMANY}

On 5 May 2020, the Federal Constitutional Court of Germany (BVerfG) ruled that the Public Sector Purchase Programme (PSPP) of the European Central Bank (ECB) was contrary to the German Federal Constitution. ${ }^{7}$ The PSPP is, in simplified terms, a so-called quantitative easing programme involving the purchase of euro-denominated marketable debt securities issued by central governments of Eurozone Member States ${ }^{8}$, probably the most significant measure of ECB responses to the European sovereign debt crisis. ${ }^{9}$

What makes this ruling even more noteworthy is that it was passed following a preliminary ruling by the Court of Justice of the EU which was requested by the FCC itself in the course of the same national constitutional complaint procedure. The questions related essentially to whether the relevant decisions of the ECB amounted to ultra vires acts and were infringing German constitutional identity. In its Weiss preliminary ruling delivered in December 2018, the Court of Justice upheld the validity of the ECB decisions. ${ }^{10}$ The Court of Justice inter alia conducted a proportionality analysis (in line with its previous findings in Gauweiler ${ }^{11}$ ) and found that Decision 2015/774 did not run counter to the proportionality principle. ${ }^{12}$

However in its 2020 judgment, the FCC found - regardless of what the preliminary ruling stated - that the ECB measures did infringe the principle of conferral and the delimitation of competences between the EU and its Member States, and were thus ultra vires. The deciding issue for the FCC was whether the PSPP could be seen as a monetary policy measure or a measure of economic policy - and as the ECB's competences related only to monetary policy, economic policy measures should be seen as falling outside the competence of the EU's central bank in any case. ${ }^{13}$ The BVerfG held that if the distinction between monetary policy and economic policy is to be made on the basis of the proportionality principle, then the effects of the ECB measures in question, i.e. the PSPP scheme (which may very well have economic effects) should be taken into account when assessing said proportionality. ${ }^{14}$ Subsequently, the FCC delivered a rather strong criticism of the preliminary ruling of the

\footnotetext{
${ }^{7}$ BVerfG, Judgment of the Second Senate of 05 May 2020 - 2 BvR 859/15. The paper comments rely on the English translation provided here: https://www.bundesverfassungsgericht.de/SharedDocs/Entscheidungen/ EN/2020/05/rs20200505_2bvr085915en.html (19 August 2020).

${ }^{8}$ Decision 2015/774/EU of the European Central Bank on a secondary markets public sector asset purchase programme (OJ 2015 L 121/20), Art. 3.

${ }^{9}$ M. Frangakis, 2017. The ECB's Non-standard Monetary Policy Measures and the Greek Financial Crisis. In: Marangos, J. (ed.), The Internal Impact and External Influence of the Greek Financial Crisis, Cham: sPalgrave Macmillan, 2017, p. 64.

${ }^{10}$ Case C-493/17 Weiss and Others [EU:C:2018:1000].

${ }^{11}$ Case C-62/14 Gauweiler and Others [EU:C:2015:400].

${ }^{12}$ Ibid., paras. 71-100.

${ }^{13}$ Mayer, F. C., 2020. Auf dem Weg zum Richterfaustrecht? Zum PSPP-Urteil des BVerfG, Verfassungsblog, 7 May 2020 https://verfassungsblog.de/auf-dem-weg-zum-richterfaustrecht/ (19. 08. 2020).

${ }^{14} 2$ BvR 859/15, para. 139.
} 
CJEU and dismissed the proportionality analysis conducted by the EU Court in Weiss as unsatisfactory and "meaningless" for the attainment of the purpose (i.e. the abovementioned distinction between economic and monetary policy goals) that it was apparently meant to serve. ${ }^{15}$ The FCC stated that the CJEU afforded the ECB way too broad discretion and at the same time did not provide the standard of review that would have been necessary. And, according to the FCC, by not scrutinizing this competence issue sufficiently, the CJEU "largely abandoned the distinction between economic policy and monetary policy" and thus authorised the ECB "to pursue its own economic policy agenda." And this "agenda", by the very fact that it is of an economic policy nature, encroaches upon the same competences of the EU Member States. This lead the German court to the conclusion that the CJEU "acted ultra vires, which is why, in that respect, its Judgment has no binding force in Germany." ${ }^{16}$ Concluding this train of thought, the Federal Constitutional Court proclaimed that no German state institution - thus not the Bundesbank either - may participate in the development or implementation of ultra vires acts such as the PSPP. ${ }^{17}$

\section{COMMENTS}

Much has been said in recent years about judicial dialogue and judicial comity (or the lack thereof) between national constitutional or supreme courts and the Court of Justice in the context of constitutional identity and ultra vires review. Neither primacy over national constitutions, nor the relationship between the Court of Justice and national constitutional courts are clear cut issues, and this is certainly not the first sign of conflict - one could refer for recent examples to the Dansk Industri ${ }^{18}$ and Landtová ${ }^{19}$ sagas. $^{20}$

In Dansk Industri, the Danish Supreme Court decided not to set aside Danish law, despite a preliminary ruling by the Court of Justice which required the Supreme Court to either interpret the relevant provisions of national law in a way that they may be applied consistently with the applicable EU directive or, in case such an interpretation was not possible, to disapply national law which ran counter to EU law (in the particular case: the general principle of non-discrimination..$^{21}$ The Danish Supreme Court failed to do

${ }^{15}$ Ibid. paras. 123-124.

${ }^{16}$ Ibid. paras 153-163.

${ }^{17}$ Nota bene: the question of the compatibility of the measures with the prohibition of monetary financing as per Article 123 TFEU was also raised but the BVerfG found utlimately that „a manifest circumvention” of that provision could - „despite the concerns” - not be ascertained (para. 216).

${ }^{18}$ See Case 15/2014 DI, acting on behalf of Ajos A/S v Estate of A. Judgment of the Supreme Court, 6 December 2016 and Case C-441/14 Dansk Industri v Rasmussen [EU:C:2016:278].

${ }^{19}$ Case C-399/09 Landtová [EU:C:2011:415].

${ }^{20}$ As pointed out by Kyriazis, D. 2020. The PSPP judgment of the German Constitutional Court: An Abrupt Pause to an Intricate Judicial Tango, European Law Blog, 6 May 2020 https://europeanlawblog.eu/2020/05/06/ the-pspp-judgment-of-the-german-constitutional-court-an-abrupt-pause-to-an-intricate-judicial-tango/(19. 08. 2020).

${ }^{21}$ Case C-441/14 Dansk Industri, paras 31-36. 
so, thereby presenting a serious challenge to the principle of primacy. ${ }^{22}$ In Landtová, the Court of Justice found that the case law of the Czech Constitutional Court regarding pension matters was in breach of the non-discrimination principles of EU law. ${ }^{23}$ The Czech Constitutional Court however ruled that the judgment of the Court of Justice was ultra vires and proclaimed that it will not change its practice. ${ }^{24}$ The PSPP ruling is also not the first time the FCC has claimed a right to review ultra vires acts of the $\mathrm{EU}^{25}$, but it is the first time that it has actually proclaimed the ultra vires nature of such an act.

It is easy to see why the PSPP ruling can be regarded as a turning point, the consequences of which a may turn out to be rather serious. ${ }^{26}$ Firstly, in a theoretical sense: together with direct effect, the primacy of EU law over national law is an essential foundational concept of the EU's autonomous legal order, and the same goes for the CJEU's exclusive jurisdiction regarding the validity of EU law. (One could also say that these are core elements of the constitutional identity of the EU itself. $)^{27}$ The professional authority of the FCC is also of relevance here: constitutional courts have long since taken note of and on occasion even expressly referred to FCC jurisprudence regarding the relationship between EU law and national constitutions in the identity review context. ${ }^{28}$ It is not hard to see why such judgments undermine the autonomy of the EU legal order. Secondly, in a practical and economic sense, the judgment could very well disrupt the PSSP programme ${ }^{29}$ - and what is more, it comes at the time of a global Covid-19 pandemic to which the ECB has among other things responded with a rather similar initiative, the Pandemic Emergency Purchase Programme (PEPP). ${ }^{30}$ Although here the FCC itself stated in its communique that the

${ }^{22}$ See Gualco, E. 2017. “Clash of Titans 2.0.” From Conflicting EU General Principles to Conflicting Jurisdictional Authorities: The Court of Justice and the Danish Supreme Court in the Dansk Industri Case.

European Papers2(1), pp. 223-229.

${ }^{23}$ Case C-399/09 Landtová, para 54.

${ }^{24}$ Ruling PL.US 5/12. For commentary in context see Várnay, E.2019. Az Alkotmánybíróság és az Európai Bíróság. Együttműködő Alkotmánybíráskodás? Állam- és Jogtudomány, 60(2), pp. 63-91, and particularly at p. 83., whereas specifically regarding the Czech ruling see: Komárek, J. 2012. Czech Constitutional Court Playing with Matches: the Czech Constitutional Court Declares a Judgment of the Court of Justice of the EU Ultra Vires; Judgment of 31 January 2012, Pl. ÚS 5/12, Slovak Pensions XVII” European Constitutional Law Review,8(2), pp. 323-337.

${ }^{25}$ See for instance the FCC's Maastricht (2 BvR 2134/92 et 2 BvR 2159/92) and OMT (2 BvR 2728/13) judgments.

${ }^{26}$ Chronowski, N. 2020. Fordulópont az európai bírói párbeszédben: a német Szövetségi Alkotmánybíróság PSPP-döntése. Közjogi Szemle, 13(2), pp.76-79.

${ }^{27}$ As discussed inter alia by Lenaerts, K. 2014. The Kadi Saga and the Rule of Law within the EU. SMU Law Review,67(4), pp. 708-709. and Mohay, Á. 2019. A nemzetközi jog érvényesülése az uniós jogban. Pécs: PTE ÁJK Európa Központ / Publikon. 2019. pp. 141-145.

${ }^{28}$ As did for example the Hungarian Constitutional Court. For an analysis of the relevant judgment see Mohay, Á.\& Tóth, N. 2017.Decision 22/2016. (XII. 5.) AB on the Interpretation of Article E)(2) of the Fundamental Law, American Journal of International Law, 111(2), pp. 468-475.

${ }^{29}$ It should nevertheless be noted that the PSPP-ruling has no retroactive effect. Tosato, G. L. 2020. The Decision of the German Constitutional Court on the Public Sector Purchase Programme of the European Central Bank: Preliminary Observations. Policy Brief 24/2020, Luiss School of European Political Economy, 6 May (2020), p. 3.

${ }^{30}$ Decision 2020/440/EU of the European Central Bank on a temporary pandemic emergency purchase programme (OJ 2020 L 91/1). 
ruling did not pertain to the $\mathrm{PEPP}^{31}$, it is difficult to imagine that the same challenge will not potentially be brought against that measure. ${ }^{32}$ One cannot help but wonder if a more nuanced response can reasonably be expected from the FCC in the context of the PEPP.

There is nevertheless a possible escape route built into the bastion of constitutional identity in the FCC ruling: the German court has determined a provisional period of no more than three months, during which the European Central Bank could adopt 'a new decision that demonstrates in a comprehensible and substantiated manner that the monetary policy objectives pursued by the ECB are not disproportionate to the economic and fiscal policy effects resulting from the programme." ${ }^{33}$ This is not uncontroversial either as thereby the FCC intends to lay down rules for a decidedly independent and decidedly EU-level institution, one which operates on the legal basis of EU law - which in turn can only be judicially reviewed by the CJEU, this jurisdictional delimitation is apparent from Article 19 TEU and Article 344 TFEU. In this light, the suggestion that the German Government and the Bundestag are to influence the ECB (granted, only to conduct a thorough proportionality analysis) is also somewhat perplexing ${ }^{34}$, even if the FCC for its part reassures all that this does not conflict with said independence. ${ }^{35}$

\section{CONCLUDING REMARKS}

Following the German decision, the CJEU issued a laconic press release recounting in no uncertain terms the binding nature of its preliminary rulings and the pivotal role that they play in the uniform interpretation and application of EU law, but - understandably without any further comment or evaluation. ${ }^{36}$ Academics have however strongly criticised the FCC judgment, lamenting the intellectual arrogance of the FCC. ${ }^{37}$

The CJEU is traditionally very protective of its own jurisdiction (consider among many others its judgment in the MOX Plant case ${ }^{38}$ or its Opinion 2/13 on EU accession to the $\mathrm{ECHR}^{39}$ ) and in the present case one can understand the cause for alarm: without the preliminary ruling procedure, direct effect and primacy would not exist, and the interpretation of EU law would no doubt see significant divergences in different Member

\footnotetext{
${ }^{31}$ https://www.bundesverfassungsgericht.de/SharedDocs/Pressemitteilungen/EN/2020/bvg20-032.html

${ }^{32}$ Kyriazis 2020.

${ }^{33} 2$ BvR 859/15, para. 235. The Bundesbank should further ensure that the bonds already purchased are sold in a method coordinated within the European System of Central Banks.

${ }^{34}$ Mayer 2020.

${ }^{35} 2$ BvR 859/15, para. 232.

${ }^{36}$ https://curia.europa.eu/jcms/upload/docs/application/pdf/2020-05/cp200058en.pdf (19 August 2020).

${ }^{37}$ Ziller, J. The Unbearable Heaviness of the German Constitutional Judge. On the Judgment of the Second Chamber of the German Federal Constitutional Court of 5 May 2020 Concerning the European Central Bank's PSPP Programme. CERIDAP 2020/2, pp. 87-99.

${ }^{38}$ Case C-459/03 Commission v Ireland [EU:C:2006:345].

${ }^{39}$ Opinion 2/13 [EU:C:2014:2454].
} 
States. The effet utile ${ }^{40}$ of the preliminary ruling procedure and EU law in general would thus be seriously imperilled, and thus the authority of EU law could be called into question: the preliminary ruling mechanism has been rightly called the central legal in the relationship between EU law and national law, so a strain on this mechanism represents a strain on the authority of Union law. ${ }^{41}$

It has been suggested that the constitutional identity clause in Art. 4(2) TEU may be utilized to reconceptualise the relationship between EU law and domestic constitutional law, paving the way towards a more nuanced interpretation of the relationship between EU law and national constitutional law, going beyond the absolute primacy doctrine applied by the CJEU. ${ }^{42}$ Perhaps this FCC ruling - which will no doubt become one of the most analysed judgments in the field of European Union law - signals among other things a need for the CJEU to engage in a more elaborate interpretation of the identity clause and its effects and limits. Of course, any judicial dialogue can only have an effect if the participants of said dialogue actually endeavour to engage in a meaningful conversation.

${ }^{40}$ Regardless of the fact that the effet utile doctrine itself is sometimes contested. Cf. Urška Šadl: The Role of Effet Utile in Preserving the Continuity and Authority of European Union Law: Evidence from the Citation Web of the Pre-accession Case Law of the Court of Justice of the EU, European Journal of Legal Studies, vol 18, 2015, pp. 19-45.

${ }^{41}$ Weiler, J. H. H. The authority of European law: Do we still believe in it? In: Heusel, W. \&Rageade, J.-P. 2019. The authority of European law: Do we still believe in it? Springer, 2019, p. 5.

${ }^{42}$ Von Bogdandy \& Schill, 2011, pp. 1417-1454. 


\section{LIST OF REFERENCES}

Chronowski, N. 2020. Fordulópont az európai bírói párbeszédben: a német Szövetségi Alkotmánybíróság PSPP-döntése. Közjogi Szemle, 13(2), pp. 76-79.

Gualco, E. 2017. "Clash of Titans 2.0.” From Conflicting EU General Principles to Conflicting Jurisdictional Authorities: The Court of Justice and the Danish Supreme Court in the Dansk Industri Case. European Papers 2(1), pp. 223-229.

Komárek, J. 2012. Czech Constitutional Court Playing with Matches: the Czech Constitutional Court Declares a Judgment of the Court of Justice of the EU Ultra Vires; Judgment of 31 January 2012, Pl. ÚS 5/12, Slovak Pensions XVII" European Constitutional Law Review, 8(2), pp. 323-337.

Konstadinides, T. 2011. Constitutional Identity as a Shield and as a Sword: The European Legal Order within the Framework of National Constitutional Settlement. Cambridge Yearbook of European Legal Studies, Vol 13, pp. 195-218.

Kyriazis, D. 2020. The PSPP judgment of the German Constitutional Court: An Abrupt Pause to an Intricate Judicial Tango, European Law Blog, 6 May $2020 \mathrm{https://europeanlawblog.}$ $\mathrm{eu} / 2020 / 05 / 06 /$ the-pspp-judgment-of-the-german-constitutional-court-an-abruptpause-to-an-intricate-judicial-tango/ (19. 08. 2020).

Lenaerts, K. 2014. The Kadi Saga and the Rule of Law within the EU. SMU Law Review, 67(4), pp. 708-709.

M. Frangakis, 2017. The ECB's Non-standard Monetary Policy Measures and the Greek Financial Crisis. In: Marangos, J. (ed.), The Internal Impact and External Influence of the Greek Financial Crisis, Cham: Palgrave Macmillan, 2017, pp 47-70.

Mayer, F. C., 2020. Auf dem Weg zum Richterfaustrecht? Zum PSPP-Urteil des BVerfG, Verfassungsblog, 7 May 2020 https://verfassungsblog.de/auf-dem-weg-zum-richterfaustrecht/ (19. 08. 2020).

Mohay, Á. 2019. A nemzetközi jog érvényesülése az uniós jogban. Pécs: PTE ÁJK Európa Központ / Publikon. 2019.

Mohay, Á. \& Tóth, N. 2017. Decision 22/2016. (XII. 5.) AB on the Interpretation of Article E) (2) of the Fundamental Law, American Journal of International Law, 111(2), pp. 468-475.

Saiz Arnaiz, A. \& Alcoberro Llivina, C. 2011. National Constitutional Identity and European Integration. Cambridge: Intersentia, 2013.

Tosato, G. L. 2020. The Decision of the German Constitutional Court on the Public Sector Purchase Programme of the European Central Bank: Preliminary Observations. Policy Brief 24/2020, Luiss School of European Political Economy, 6 May (2020), pp. 1-3.

Várnay, E. 2019. Az Alkotmánybíróság és az Európai Bíróság. Együttmüködő Alkotmánybíráskodás? Állam- és Jogtudomány, 60(2), pp. 63-91. 
Von Bogdandy, A. \& Schill, S. 2011. Overcoming Absolute Primacy: Respect for National Identity under the Lisbon Treaty, Common Market Law Review, 48(5), pp. 1417-1454.

Weiler, J. H. H. The authority of European law: Do we still believe in it? In: Heusel, W. \& Rageade, J.-P. 2019. The authority of European law: Do we still believe in it? Berlin: Springer, 2019, pp. 3-20.

Ziller, J. The Unbearable Heaviness of the German Constitutional Judge. On the Judgment of the Second Chamber of the German Federal Constitutional Court of 5 May 2020 Concerning the European Central Bank's PSPP Programme. CERIDAP 2020/2, pp. 87-99.

\section{LEGAL SOURCES AND CASE-LAW}

Amministrazione delle Finanze dello Stato v. Simmenthal SpA, 1978. CJEU, Judgment of the Court of 9 March 1978. (Case 106/77, EU:C:1978:49) Available at: http://curia.europa. eu/juris/celex.jsf?celex=61977CJ0106\&lang $1=$ en\&type $=$ TXT\&ancre(19. 08. 2020).

Commission v Ireland, 2006. CJEU, Judgment of the Court (Grand Chamber) of 30 May 2006. (Case C-459/03, EU:C:2006:345) Available at: http://curia.europa.eu/juris/celex. jsf?celex $=62003$ CJ0459\&lang $1=$ en\&type $=$ TXT\&ancre $(19.08 .2020)$.

Dansk Industri v Rasmussen, 2016. CJEU, Judgment of the Court (Grand Chamber) of 19 April 2016. (Case C-441/14, EU:C:2016:278) Available at: http://curia.europa.eu/ juris/celex.jsf?celex=62014CJ0441 \&lang1=en\&type=TXT\&ancre (19. 08. 2020).

Decision of the German Federal Constitutional Court of October 12, 1993 In Re Maastricht Treaty, 1993. BVerfGe. (2 BvR 2134/92 et 2 BvR 2159/92).

ECB decisions on the Public Sector Purchase Programme exceed EU competences. 2020, BVerfGe, Press Release of the BVerfGe of 05 May 2020. (Press Release No. 32/2020) Available at: https://www.bundesverfassungsgericht.de/SharedDocs/Pressemitteilungen/ EN/2020/bvg20-032.html (19. 08. 2020).

EU Decision 2015. EU, Decision of the European Central Bank of 4 March 2015 on a secondary markets public sector asset purchase programme. (2015/774/EU, OJ 2015 L 121/20) Art. 3.

EU Decision 2020. EU, Decision of the European Central Bank of 24 March 2020 on a temporary pandemic emergency purchase programme. (2020/440/EU, OJ 2020 L 91/1).

EU Declaration 2008. EU, Declaration concerning primacy, annexed to the Final Act of the Intergovernmental Conference, Official Journal of the European Union 115 of 09 May 2008. (OJ C 115) p. 344.

Flaminio Costa v. E.N.E.L. 1964. CJEU, Judgment of the Court of 15 July 1964. (Case 6/64, EU:C:1964:66) Available at: https://eur-lex.europa.eu/legal-content/EN/ TXT/?uri=CELEX\%3A61964CJ0006 (19. 08. 2020). 
Gauweiler and Others, 2015. CJEU, Judgment of the Court (Grand Chamber) of 16. June 2015. (Case C-62/14, EU:C:2015:400) Available at: http://curia.europa.eu/juris/celex. jsf?celex=62014CJ0062\&lang $1=$ en\&type $=$ TXT\&ancre $(19.08 .2020)$.

Internationale Handelsgesellschaft mbH $v$ Einfuhr-und Vorratsstelle für Getreide und Futtermittel. 1970, CJEU, Judgment of the Court of 17 December 1970. (EU:C:1970:114) Available at: http://curia.europa.eu/juris/celex.jsf?celex=61970CJ0011\&lang1=en\&type=TXT\&ancre (19.08. 2020).

Judgment of the Second Senate of 05 May 2020, 2020, BVerfGe, Judgment of the Second Senate of 05 May 2020. (2 BvR 859/15) Available at: https://www.bundesverfassungsgericht. de/SharedDocs/Entscheidungen/EN/2020/05/rs20200505_2bvr085915en.html (19. 08. 2020).

Judgment of the Second Senate of 21 June 2016, 2016, BVerfGe, Judgment of the Second Senate of 21 June 2016. (2 BvR 2728/13). Available at: https://www.bundesverfassungsgericht. de/SharedDocs/Entscheidungen/EN/2016/06/rs20160621_2bvr272813en.html (19. 08. 2020).

Marie Landtová v Česká správa socialního zabezpečení, 2011. CJEU, Judgment of the Court (Fourth Chamber) of 22 June 2011. (Case C-399/09, EU:C:2011:415) Available at: http:// curia.europa.eu/juris/celex.jsf?celex=62009CJ0399\&lang1=en\&type=TXT\&ancre $(19$. 08. 2020).

Opinion 2/13, 2014. CJEU, Opinion of the Court (Full Court) of 18 December 2014. (EU:C:2014:2454) Available at: http://curia.europa.eu/juris/celex. jsf? celex $=62013 \mathrm{CV} 0002 \&$ lang $1=$ en\&type $=$ TXT\&ancre $(19.08 .2020)$.

Press release following the judgment of the German Constitutional Court of 5 May 2020, 2020, CJEU, Press release of the Court of Justice of the European Union of 08 May 2020. (Press Release No. 58/20) Available at: https://curia.europa.eu/jcms/upload/docs/ application/pdf/2020-05/cp200058en.pdf (19. 08. 2020).

Ruling PL.US 5/12, 2012. Czech Republic Constitutional Court, Judgment of the Czech Republic Constitutional Court of 31 January 2012. (Pl. US 5/12).

Solange I Urteil, 1974, BVerfGE, Beschluß des Zweiten Senats vom 29. Mai 1974. (BVerfGE, 37, 271) Available at: https://www.servat.unibe.ch/dfr/bv037271.html (19. 08. 2020).

Van Gend en Loos v. Nederlandse administratie der belastingen, 1963. CJEU, Judgment of the Court of 5 February 1963. (Case 26/62, EU:C:1963:1) Available at: https://eur-lex. europa.eu/legal-content/EN/TXT/?uri=CELEX\%3A61962CJ0026 (19. 08. 2020).

Weiss and Others, 2018. CJEU, Judgment of the Court (Grand Chamber) of 11 December 2018. (Case C-493/17, EU:C:2018:1000) Available at: http://curia.europa.eu/juris/celex. jsf?celex=62017CJ0493\&lang $1=$ en\&type $=$ TXT\&ancre $(19.08 .2020)$. 